\section{Investigation of ceramic brick rods with blackened materials inside}

EMESE KUROVICS - Institute of Ceramics and Polymer Engineering, University of Miskolc • fememese@ uni-miskolc.hu

Sergeı N. KULKOV - Institute of Strength Physics and Materials Science of Siberian Branch of Russian Academy of Sciences, National Research Tomsk State University - kulkov@ms.tsc.ru

LÁszLó A. GÖMZE - Institute of Ceramics and Polymer Engineering, University of Miskolc - femgomze@ uni-miskolc.hu

Érkezett: 2018. 01. 15. - Received: 15. 01. 2018. " https://doi.org/10.14382/epitoanyag-jsbcm.2018.1

\section{Abstract}

In this work the authors have studied the blackened materials inside of the ceramic rods after their sintering in a laboratory chamber kiln. The samples were extruded from conventional brick clays of mined moistures after mixing with additives of sawdust and sunflower husk in $2.91 \mathrm{~m} \%$ and $3.85 \mathrm{~m} \%$. During the investigation they found a considerable influence of vegetable origin additives on chemical, physical and mechanical properties of sintered materials including color, microstructure, mineral and chemical compositions as well as mechanical strength, drying and firing shrinkages. The mineralogical compositions and morphological structures of the "fired out" sawdust and sunflower husks were also determined inside of the blackened parts of specimens. Thanking to the heat generated by fired out vegetable origin additives a remarkable quantity of glass phase components was also formed in the blackened parts of the sintered rods.

Keywords: material structures, ceramic, composites, hercynite, minerals, mineralization, sawdust, sunflower husk
Emese KUROVICS, is graduated in the University of Miskolc, Department of Ceramics and Silicate Engineering as a material engineer, where she actually continues her study as PhD student under supervision of Prof. L. A. Gömze.

Sergei N. KULKOV, is professor of the Tomsk State University and head of Department of Ceramics in the Institute of Strength Physics and Materials Science of the Russian Academy of Science since 1989. His research works are represented in 5 books, more than 150 articles, 18 patents and many International Symposiums and Conferences. At present he is head of department "Theory of Strength and Mechanic of Solids", member of The American Ceramic Society" of "The APMIInternational" and the DYM AT Society (France).

László A. GÖMZE, is establisher and professor of the Department of Ceramics and Silicate Engineering in the University of Miskolc, Hungary. He is author or coauthor of 2 patents, 6 books and more than 300 scientific papers. Recently, he is the chair of the International Organization Board of ic-cmtp5 the 5th International Conference on Competitive Materials and Technological Processes (2018).

\section{Introduction}

The clay minerals are one of the oldest materials which were used by humanity [1]. Clays are used also more than 7,000 years [2] to prepare building materials. In spite of the clay minerals are used by thousand years their study and examination are in the focus of research in several segments of science [3-10] and industry [11-18] until today. In our days the brick and ceramic roof tiles industries are the largest user of the conventional brick clays [19-29]. In spite of the large production volume of brick and ceramic roof tile industries and intensive research of the conventional brick clays the drying sensitivity and material structure inhomogeneity can be reason of the scrap formations and quality defaults.

The goals of this research are to understand the influence of vegetable organic additives on chemical, physical and mechanical properties of conventional brick products including their colors, microstructures, mineral and chemical compositions, mechanical strengths as well as drying and firing shrinkages.

\section{Materials and methods}

During the experiment the authors have used conventional brick clays with moistures of $21-23 \mathrm{~m} \%$ of relative humidity and sawdust or sunflower husks and mixed them in a pan mill type planetary rotary mixture at 90rpm through 10 minutes (Table 1). From each mixture cylindrical shape rods were extruded with diameter of $25 \mathrm{~mm}$ on a KEMA-PVP 5/S extruder. After extrusions the rods were cut by 14 specimens, 6 from them with $50 \mathrm{~mm}$ for pressure strength test and 8 from them with $150 \mathrm{~mm}$ lengths for bending strength test. The so prepared specimens were dried in a laboratory chamber-dryer at $50^{\circ} \mathrm{C}$ during 72 hours.

\begin{tabular}{ccc} 
Clay & Sawdust & Sunflower husk \\
97.09 & 2.91 & - \\
\hline 96.15 & 3.85 & - \\
\hline 97.09 & - & 2.91 \\
\hline 96.15 & - & 3.85
\end{tabular}

Table 1. Mixture composition in $m \%$

1. táblázat A keverékek összetétele tömegszázalékban [m\%]

The produced and dried cylindrical rod specimens were sintered in a laboratory chamber kiln at a heating rate of $60^{\circ} \mathrm{C} /$ hour up to $950^{\circ} \mathrm{C}$ and keep at this temperature through 2 hours to generate the required solid phase transformations of the clay minerals and mineral components of sawdust and sunflower husk. After these 2 hours keeping at maximum temperature the kiln heating system was switched off and cooled down freely at closed door.

\section{Results and discussion}

During the experiments the authors have determined the linearly and volumetrically drying and sintering shrinkages together with the mass losses. After the sintering the specimens with $50 \mathrm{~mm}$ green length were subjected under compressive strength and the specimens with $150 \mathrm{~mm}$ green length under bending strength. The average values of volume shrinkages, weight losses, bending and compressive strengths are shown in Table 2.

After the fractures it was surprising that the sintered ceramic materials inside of each specimen became black colors meanwhile they were covered with the red-brown material shells (Figure 1) with thickness of $1.5-2 \mathrm{~mm}$. One of the reasons of this phenomenon can be the very fine grain structure of the used clay minerals with large volumes of submicron and nano 


\begin{tabular}{|c|c|c|c|c|c|}
\hline \multicolumn{2}{|c|}{ Additive, m\% } & \multirow[t]{2}{*}{ Volume shrinkage, \% } & \multirow[t]{2}{*}{ Weight loss, \% } & \multirow{2}{*}{$\begin{array}{l}3 \text { point bending } \\
\text { strength, MPa }\end{array}$} & \multirow{2}{*}{$\begin{array}{l}\text { Compressive } \\
\text { strength, MPa }\end{array}$} \\
\hline Sawdust & Sunflower husk & & & & \\
\hline 2.91 & - & 12.25 & 23.75 & 9.28 & 30.26 \\
\hline 3.85 & - & 12.34 & 23.83 & 9.48 & 32.09 \\
\hline- & 2.91 & 9.54 & 23.42 & 8.67 & 29.90 \\
\hline- & 3.85 & 10.25 & 22.73 & 13.08 & 34.22 \\
\hline
\end{tabular}

Table 2. Characteristics of specimens made from mixtures of different compositions 2. táblázat A különböző keverékekből készült minták jellemzői

particles. In this case the sawdust and sunflower husk additives could not get oxygen enough to turn into gas phase and fire out. At $950^{\circ} \mathrm{C}$ temperature the firing sawdust and sunflower husk additives could reduce the 3 valence iron-oxide atoms and promote formations of hercynite minerals, thanking to the deficiency of atmosphere air and oxygen.

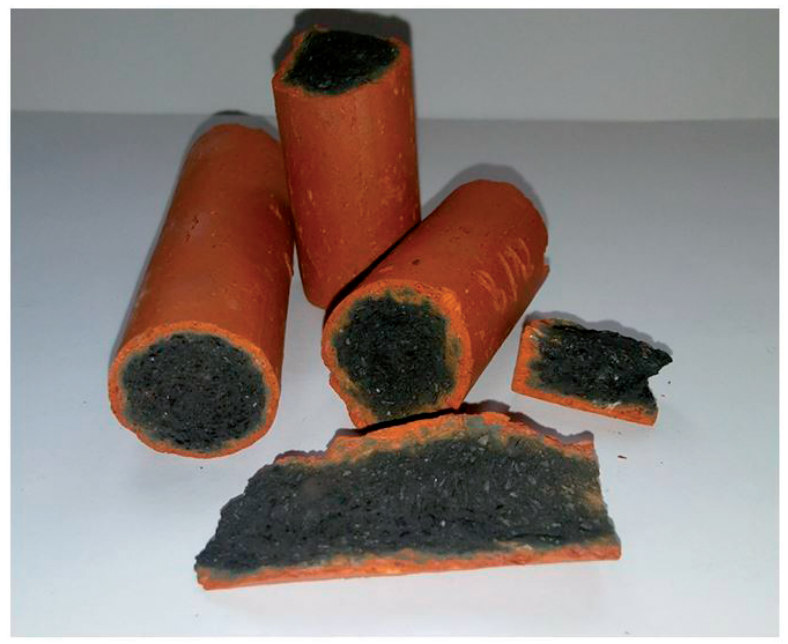

Fig. 1. The cross-section of fired and cracked specimens

1. ábra A kiégetett és eltört próbatestek keresztmetszete

The material structure and morphology of the cracked specimens were examined by Hitachi TM-1000 scanning electron microscopy. The SEM pictures show briefly that the used sawdust particles have saved their cell type microstructures and morphologies (Figure 2 and 3 ) in spite of their transformation into ceramics during the heat treatment and sintering. In Figure 3 the mineralization of sawdust cell structure is very similar to the material structures of the remnants of organic pore-forming additives in conventional clay brick materials which were described by F Kristály and L A Gömze [3] in 2008.

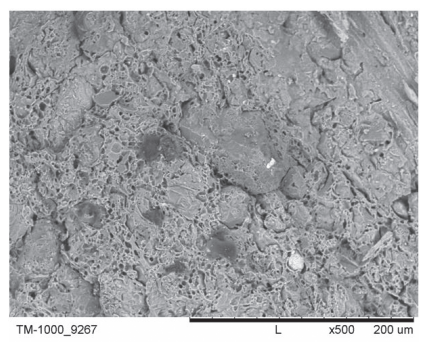

(a)

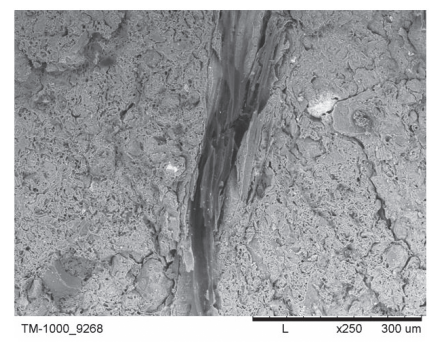

(b)
Fig. 2. The fracture surface of sintered specimens with sawdust 2. ábra Fürészpor tartalmú szinterelt próbatest töretfelülete

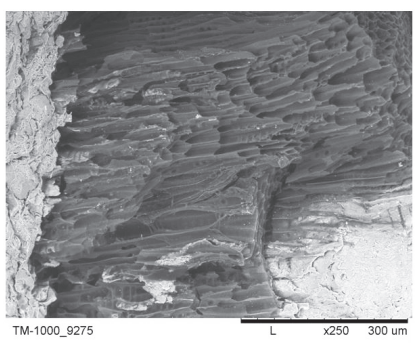

(a)

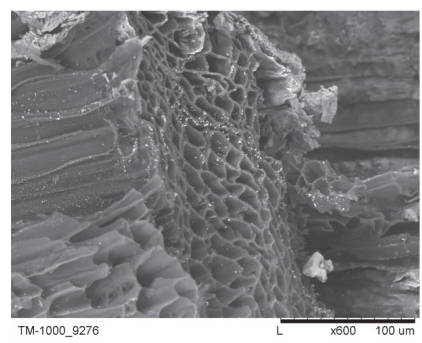

(b)
Fig. 3. The sawdust transformed into ceramics inside of the specimens 3. ábra A keramizálódott fürészpor a minta belsejében

To determine the elementary chemical compositions the specimens were further examined on scanning electron microscope ZEISS EVO MA10 serviced with energy dispersive microswitch (EDAX). The microstructure and material composition of the red-brown cylindrical shell are shown in Figure 4 and the microstructure and material composition of the blackened surfaces inside of the rods are shown in Figure 5. It is seen very well in Figure 5 how the dense and dark quartz particles are bonded in the "ceramic matrix" of the sintered clay minerals.
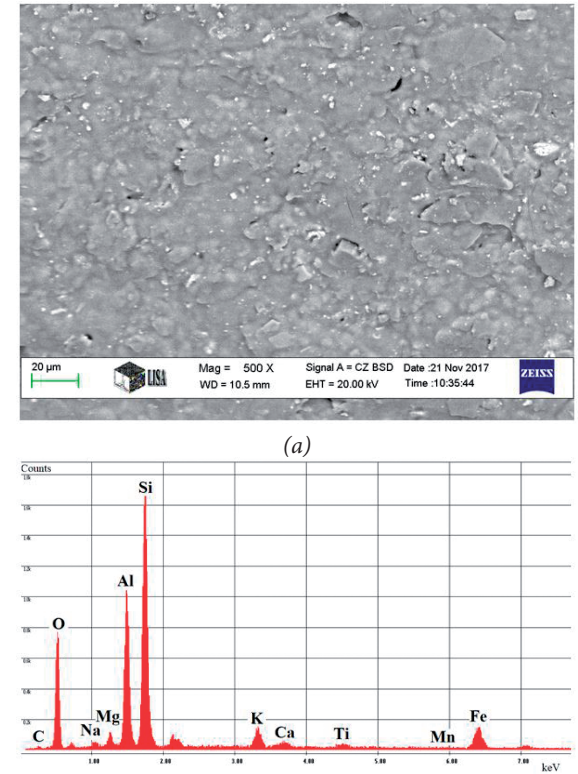

(b)

Fig. 4. The microstructure (a) and chemical compositions (b) of specimens with sunflower husks at the red-brown surface

4. ábra A napraforgóhéjjal készült próbatest külsö, téglavörös színü felületének a mikrostruktúrája (a) és a kémiai összetétele (b)

The determined by EDAX chemical components of the darkened materials are fixed in the Table 3. 

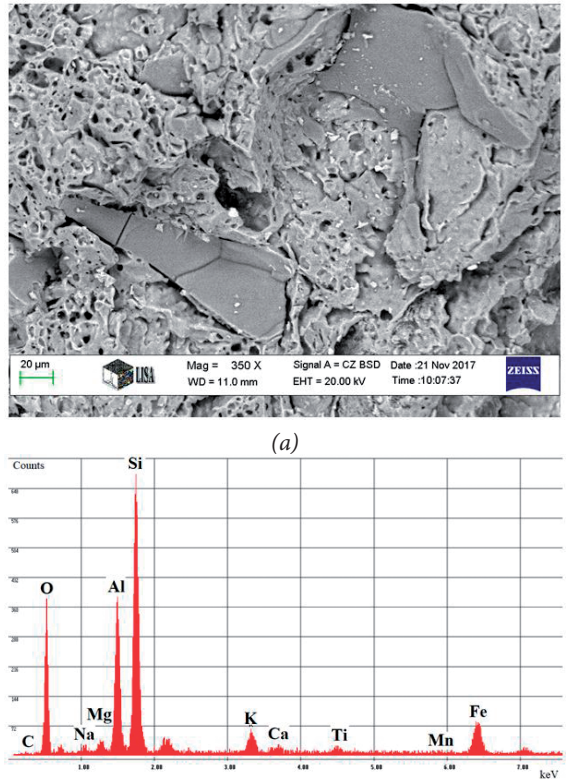

(b)

Figure 5. The microstructure (a) and chemical compositions (b) of specimens with sunflower husks at blackened surface

5. ábra A napraforgóhéjjal készült próbatest belső, fekete szinü felületének a mikrostruktúrája (a) és a kémiai összetétele (b)

Analyzing the data in Table 3 a considerable difference can be seen between carbon $(\mathrm{C})$, oxygen $(\mathrm{O})$, calcium $(\mathrm{Ca})$ and iron $(\mathrm{Fe})$ components depending on their geometrical (outside or inside) positions. This $3.0 \mathrm{~m} \%$ of carbon (C) can be also the reason of the observed blackening of material particles inside of the rod specimens.

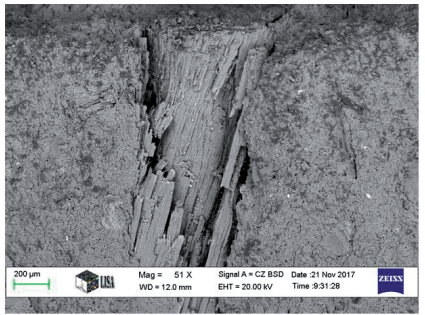

(a)

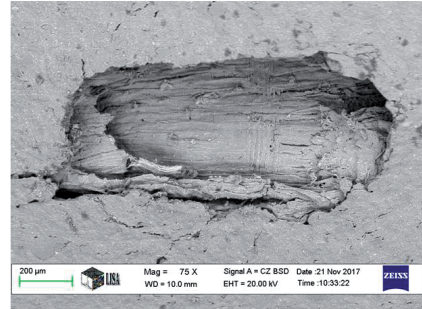

(b)
Fig. 6. The sunflower husks transformed into ceramics inside of the specimens (a) and in an outside surface crack (b)

6. ábra A keramizálódott napraforgóhéj a minta belsejében (a) és egy külső felület repedésben (b)

The transformation of sunflower husks into ceramics was examined both in inside and outside surface cracks and they are shown in Figure 6. The cell structures of the sunflower husk are saved after sintering at $950^{\circ} \mathrm{C}$ in spite of their transformation into ceramics.

The examined structure of blackened materials inside of the extruded and sintered rod specimens had a wide range but all of them are looking like a sponge. This variety of sponge structures is very well seen in the Figure 7 where the difference $(1,2)$ in chemical composition of materials (Table 4) influence not only on pore structures but on the darkness also.
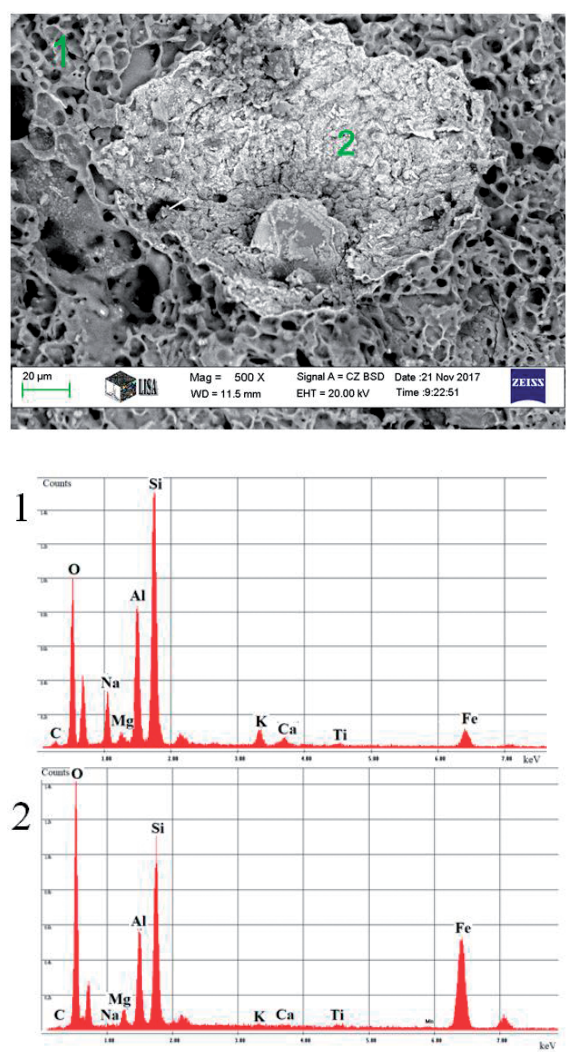

Fig. 7. The sponge structures and chemical compositions of blackened materials examined by EDAX

7. ábra A fekete anyagra jellemzö szivacs struktúra és annak kémiai összetétele $(E D A X)$

The mineral and oxide composition of the blackened materials inside of the extruded and sintered ceramic rod samples were determined by XRD examination (Figure 8). The material composition includes minerals and oxides are given in Table 5.

\begin{tabular}{|c|c|c|c|c|c|c|c|c|c|c|c|c|}
\hline & Chemical elements & C & 0 & $\mathrm{Na}$ & Mg & Al & Si & $\mathbf{K}$ & $\mathrm{Ca}$ & $\mathbf{T i}$ & Mn & $\mathrm{Fe}$ \\
\hline \multirow{2}{*}{ Wt $\%$} & The red-brown surface (outside) & 1.7 & 26.1 & 0.8 & 1.4 & 17.1 & 34.5 & 3.5 & 1.2 & 1.2 & 0.3 & 12.1 \\
\hline & The blackened surface (inside) & 3.0 & 35.5 & 0.9 & 1.1 & 14.2 & 33.2 & 2.7 & 0.8 & 0.9 & 0.3 & 7.4 \\
\hline
\end{tabular}

Table 3. The chemical compositions of the darkened materials examined and determined by EDAX

3. táblázat A minták felületének EDAX segítségével meghatározott kémiai összetétele

\begin{tabular}{|c|c|c|c|c|c|c|c|c|c|c|c|}
\hline \multicolumn{2}{|c|}{ Chemical elements } & C & 0 & $\mathrm{Na}$ & Mg & Al & Si & $\mathbf{K}$ & Ca & Ti & $\mathrm{Fe}$ \\
\hline \multirow{2}{*}{ Wt \% } & 1 & 3.40 & 29.97 & 6.30 & 1.08 & 14.38 & 31.22 & 2.54 & 1.54 & 0.80 & 8.78 \\
\hline & 2 & 1.37 & 27.46 & 0.26 & 1.99 & 9.83 & 18.73 & 0.29 & 0.30 & 0.56 & 39.20 \\
\hline
\end{tabular}

Table 4. The chemical compositions of the examined by EDAX blackened material with sponge structure

4. táblázat A szivacs struktúrájú fekete anyag EDAX segítségével meghatározott kémiai összetétele 


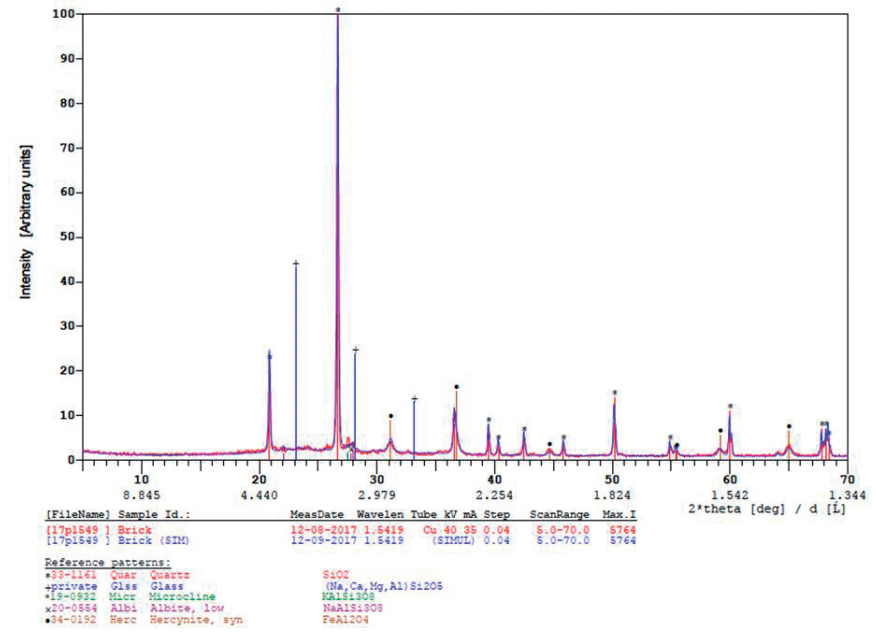

Fig. 8. The XRD diagram of the tested blackened materials with sponge structures 8. ábra A vizsgált megfeketedett szivacs szerkezetü anyag XRD diagramja

\begin{tabular}{|c|c|c|c|c|c|c|}
\hline & SUM & $\begin{array}{l}\text { Quartz } \\
\mathrm{SiO}_{2}\end{array}$ & $\begin{array}{c}\text { Glass } \\
(\mathrm{Na}, \mathrm{Ca}, \mathrm{Mg} \text {, } \\
\text { Al) } \mathrm{Si}_{2} \mathrm{O}_{5}\end{array}$ & $\begin{array}{l}\text { Microcline } \\
\mathrm{KAISi}_{3} \mathrm{O}_{8}\end{array}$ & $\begin{array}{l}\text { Albite } \\
\text { NaAl- } \\
\mathrm{Si}_{3} \mathrm{O}_{8}\end{array}$ & $\begin{array}{l}\text { Hercynite } \\
\mathrm{FeAl}_{2} \mathrm{O}_{4}\end{array}$ \\
\hline $\begin{array}{c}\text { Phase } \\
\%\end{array}$ & 100,00 & 45.00 & 35.00 & 3.00 & 5.00 & 12.00 \\
\hline $\mathrm{Fe}_{2} \mathrm{O}_{3}$ & 5.51 & & & & & 5.51 \\
\hline $\mathrm{CaO}$ & 2.39 & & 2.39 & & & \\
\hline $\mathrm{K}_{2} \mathrm{O}$ & 0.51 & & & 0.51 & & \\
\hline $\mathrm{SiO}_{2}$ & 75.98 & 45.00 & 25.60 & 1.94 & 3.44 & \\
\hline $\mathrm{Al}_{2} \mathrm{O}_{3}$ & 9.10 & & 0.54 & 0.55 & 0.97 & 7.04 \\
\hline MgO & 0.86 & & 0.86 & & & \\
\hline $\mathrm{Na}_{2} \mathrm{O}$ & 6.20 & & 5.61 & & 0.59 & \\
\hline LOI & -0.55 & & & & & -0.55 \\
\hline
\end{tabular}

Table 5. Minerals and oxides composition determined by X-ray diffraction 5. táblázat A röntgen-diffrakcióval meghatározott ásványi és oxidos összetétel

It is obvious from XRD that the carbons are presented in amorphous phase and they are included in the glass components of X-ray diffraction. The black color of the materials inside of the rods can be understandable thanking to these amorphous carbons and the relatively high value of $\mathrm{FeAl}_{2} \mathrm{O}_{4}$ hercynite mineral which have been built from one molecule $\mathrm{FeO}$ and one molecule $\mathrm{Al}_{2} \mathrm{O}_{3}$.

\section{Conclusion}

The presented research work has revealed the complexity of influence of sawdust and sunflower husks both on the morphological and material composition and colors of the ceramic items sintered from conventional brick clays. The formed inside of the body sponge structure can increased the thermo isolating properties of walls built from bricks made with pore forming additive like sawdust and sunflower husk $[3,30]$. It is necessary underpin that with increasing the portion both of sawdust and sunflower husk up to $3.85 \mathrm{~m} \%$ the compressive and bending strengths of the sintered products (bricks) will be increased.

\section{Acknowledgement}

This work was carried out with partial support of project \#14.584.21.0026 (RFMEFI58417X0026).

This work was supported partly by EFOP-3.6.1-16-201600011 and implemented in the framework of the Szechenyi 2020 program and co-financed by the European Social Fund.

\section{References}

[1] Ring, Terry A. (1995): Fundamental of Ceramic Powder Processing and Synthesis, Academic Press, San Diego, New York, Boston, London, Sydney, Tokyo, Toronto

[2] Gömze, L. A. (2001): Chapter 3 pp 30- 51 in Ceramic yearbook 2001 ÉTK and MÉASZ, Budapest

[3] Kristály, F. - Gömze, L. A. (2008): Építőanyag-JSBCM 60 (2) 34 http://dx.doi.org/10.14382/epitoanyag-jsbcm.2008.7

[4] Sharafimasooleh, M. - Bazgir, S. - Tamizifar, M. - Nemati, A. (2011): IOP Conf. Ser.: Mater. Sci. Eng. 18182012 https://doi.org/10.1088/1757-899X/18/18/182012

[5] Paineau, E. - Dozov, I. - Antonova, K. - Davidson, P. - Impéror, M. Meneau, F. - Bihannic, I. - Baravian, C. - Philippe, A. M. - Levitz, P. - Michot, L. J. (2011): IOP Conf. Ser.: Mater. Sci. Eng. 18062005 https://doi.org/10.1088/1757-899X/18/6/062005

[6] Sperberga, I. - Sedmale, G. - Stinkulis, G. - Zeila, K. - Ulme, D. (2011): IOP Conf. Ser.: Mater. Sci. Eng. 18222027 https://doi.org/10.1088/1757-899X/18/22/222027

[7] Khramchenkov, M. G. - Usmanov, R. M. (2017): Építőanyag-JSBCM 69 (4) 110 http://dx.doi.org/10.14382/epitoanyag-jsbcm.2017.19

[8] Kotova, O. (2013): IOP Conf. Ser.: Mater. Sci. Eng. 47012037 https://oi.org/10.1088/1757-899X/47/1/012037

[9] Rundans, M. - Sperberga, I. - Sedmale, G. (2016): IOP Conf. Ser.: Mater. Sci. Eng. 123012042 https://doi.org/10.1088/1757-899X/123/1/012042

[10] Csáki, Š. - Štubňa, I. - Trnovcová, V. - Ondruška, J. - Vozár, L. - Dobroň, P. (2017): IOP Conf. Ser.: Mater. Sci. Eng. 175012041 https://doi.org/10.1088/1757-899X/175/1/012041

[11] Gömze, L. A. - Gömze, L. N. (2008): Építőanyag-JSBCM 60 (4) 102 http://dx.doi.org/10.14382/epitoanyag-jsbcm.2008.16

[12]Kocserha, I. - Gömze, L. A. (2010): Applied Clay Science 48 (3) 425 http://dx.doi.org/10.1016/j.clay.2010.01.017

[13]Perng, L. H. - Huang, H-H. (2011): IOP Conf. Ser.: Mater. Sci. Eng. 18062016 https://doi.org/10.1088/1757-899X/18/6/062016

[14] Wasanapiarnpong, T. - Thueploy, A. - Nilpairach, S. - Arayaphong, D. (2011): IOP Conf. Ser.: Mater. Sci. Eng. 18222018 https://doi.org/10.1088/1757-899X/18/22/222018

[15] Sedmale, G. - Korovkins, A. - Seglins, V. - Lindina, L. (2013): IOP Conf. Ser.: Mater. Sci. Eng. 47012056 https://doi.org/10.1088/1757-899X/47/1/012056

[16] Szőke, A. M. - Muntean, M. - Sándor, M. - Brotea, L. (2016): IOP Conf. Ser.: Mater. Sci. Eng. 123012043 https://doi.org/10.1088/1757-899X/123/1/012043

[17] Kurovics, E. - Buzimov, A. Y. - Gömze, L. A. (2016): IOP Conf. Ser.: Mater. Sci. Eng. 123012058 https://doi.org/10.1088/1757-899X/123/1/012058

[18] Csáki, S. - Trnovcova, V. - Ornduska, J. - Stubna, I. - Dobron, P. Václavu, T. - Záleská, M. - Bacik, P. (2017): AIP Conference Proceedings 1866 (1) 04009 http://dx.doi.org/10.1063/1.4994489

[19] Sarani, N. A. - Kadir, A. A. (2013): Advenced Materials Research 690-693 pp 919 https://doi.org/10.4028/www.scientific.net/AMR.690-693.919

[20] Kadir, A. A. - Hinta, H. - Sarani, N. A. (2015): ARPN Journal of Engineering and Applied Science 10 (15) 6289 ISSN 1819-6608

[21] Aouba, L. - Coutand, M. - Perrin, B. - Lemercier, H. (2015): Journal of Building Physics https://doi.org/10.1177/1744259115571078

[22] Kalmár, J. - Kocsis-Buruzs, G. (2016): Építőanyag-JSBCM 68 (4) 105 http://dx.doi.org/10.14382/epitoanyag-jsbcm.2016.18

[23] Munoz, V. P. - Morales, M. P. - Letelier, G. V. - Mendívil G., M. A. (2016): Construction and Building Materials 125241 http://dx.doi.org/10.1016/j.conbuildmat.2016.08.024 
[24] Korah, L. V. - Nigay, P-M. - Cutard, T. - Nzihou, A. - Thomas, S. (2016): Construction and Building Materials 125654 http://dx.doi.org/10.1016/j.conbuildmat.2016.08.094

[25] Tantawy, M. A. - Mohamed, R. S. A. (2017): Applied Clay Science 138114 http://dx.doi.org/10.1016/j.clay.2017.01.005

[26] Safeer, A. - Yassen, I. - Raz, M. (2017): Boletin de la Sociedad Espanola de Ceramica y Vidrio 56 (3) http://dx.doi.org/10.1016/j.bsecv.2017.02.001

[27] Nigay, P-M. - Sani, R. - Cutard, T. - Nzihou, A. (2017): Materials Science and Engineering A 708 http://dx.doi.org/10.1016/j.msea.2017.09.131

[28] Sveda, M. - Sokolar, R. - Janík, B. - Stefunková, Z. (2017): Materials Science 23 (2) http://dx.doi.org/10.5755/j01.ms.23.2.15103

[29] Dominguez, D. - Munoz, V. P. - Munoz, V. L. (2017): Materiales de Construcccón 67 (328) 133 http://dx.doi.org/10.3989/mc.2017.03316

[20] Bánhidi, V. - Gömze, L. A. (2008): Materials Science Forum 5891 http://dx.doi.org/10.4028/www.scientific.net/MSF.589.1

\section{Ref.:}

Kurovics, Emese- Kulkov, Sergei N.- Gömze, László A.: Investigation of ceramic brick rods with blackened materials inside

Építőanyag - Journal of Silicate Based and Composite Materials,

Vol. 70, No. 1 (2018), 3-7. p.

https://doi.org/10.14382/epitoanyag-jsbcm.2018.1

\section{Belsejében megfeketedett kerámia tégla rudak vizsgálata}

Jelen munkában a szerzốk olyan kerámia rudakat tanulmányozták, amelyek belsejében fekete anyag jelent meg a laboratóriumi kamrás kemencében történố szinterelés után. A vizsgált mintákat hagyományos bányanedves téglaagyag és adalékanyag (fúrészpor vagy napraforgóhéj, 2,91\% és 3,85\%-ban) keverése után extrudálták. A vizsgált növényi eredetú adalékanyagoknak jelentốs a hatása a termék kémiai, fizikai és mechanikai tulajdonságaira, mint a szín, mikrostruktúra, ásványi és kémiai összetétel, valamint a mechanikai szilárdság, száradási és égetési zsugorodás. A kiégett növényi eredetũ adalékanyagok által termelt hônek köszönhetôen figyelemre méltó mennyiségú üvegfázisú amorf komponensek is létrejöttek a szinterelt kerámia rudak belsố megfeketedett részében.

Kulcsszavak: anyagszerkezet, kerámia, kompozit, hercinit, ásványok, mineralizáció, fưrészpor, napraforgóhéj

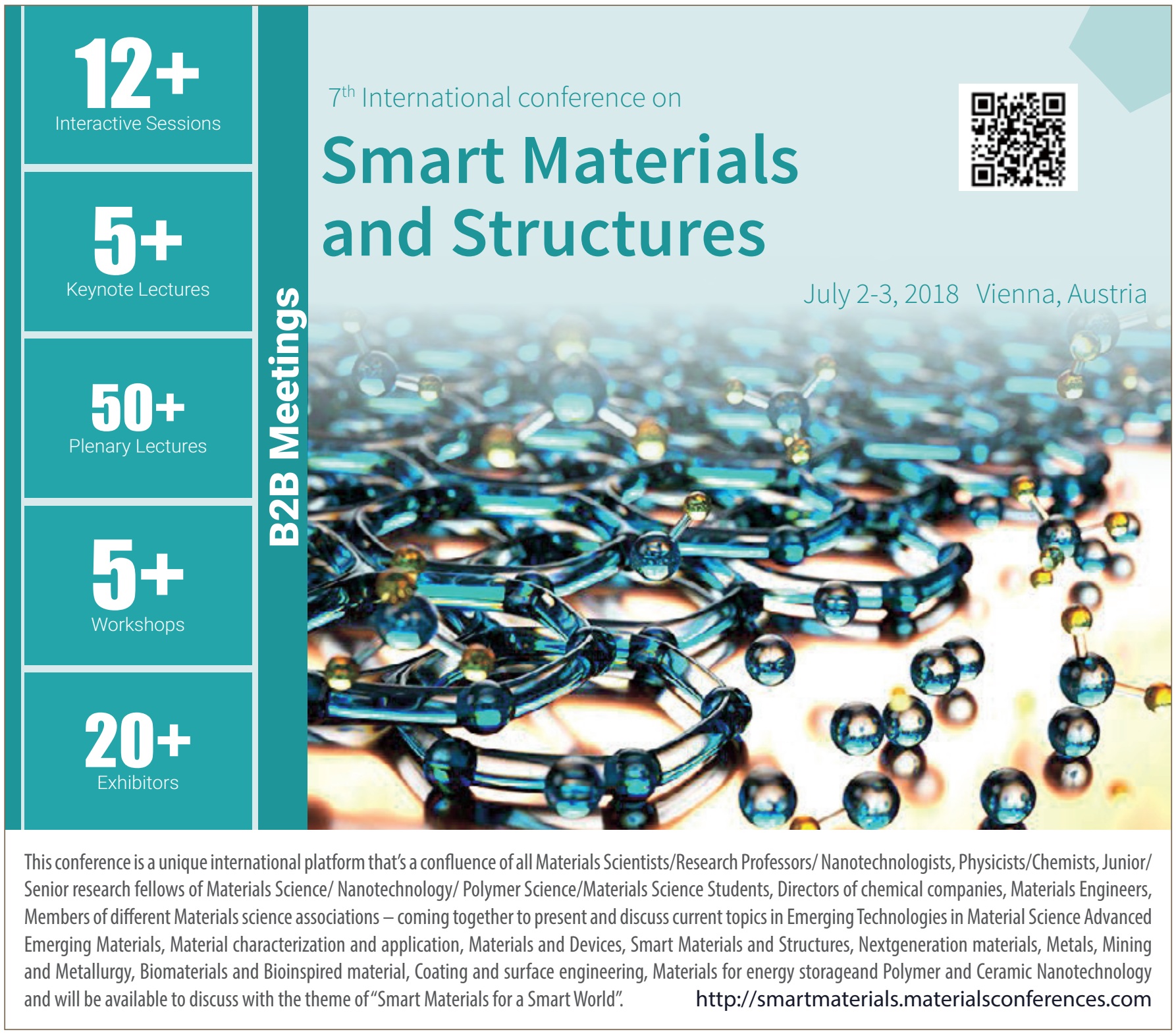

